\title{
METHODOLOGICAL APPROACH TO THE INTEGRAL ASSESSMENT OF THE REGIONAL LANDS USE TERRITORIAL DEVELOPMENT
}

\author{
Kostiantyn MAMONOV $\mathbb{D}$ \\ Department of Land Administration and Geoinformation Systems, O. M. Beketov National University of Urban \\ Economy in Kharkiv, 17, Marshala Bazhanova str., 61002 Kharkiv, Ukraine
}

Received 18 February 2019; accepted 18 September 2019

\begin{abstract}
The relevance of the research topic is caused by the need to ensure the territorial development of land use at the regional level. In this context, it is necessary to form a quantitative basis for assessing territorial development, which will make decisions in the field of land use and ensure the growth of land use efficiency in the region, considering spatial, urban planning, ecological and investment areas. As a result of the study, a methodological approach to the integrated assessment of the territorial development of land use in the region has been proposed. Its development is based on the application of principles and includes a set of interrelated stages. It was established that the formation of a complex of spatial, urban planning, investment, and ecological factors, which influence the territorial development of land use in the region is carried out on the basis of the analysis and systematization of existing scientific and methodological developments and regulatory support. An algorithm for the development and implementation of a methodological approach to an integrated assessment of the territorial development of land use in the region is proposed. It forms a closed system, which allows to develop and implement a methodological approach by applying of information support, appropriate methods and models to achieve a result on the growth of the integral indicator of land use in the region, considering spatial, urban planning, investment, and ecological characteristics. Based on the developed method, an estimated basis for the territorial development of land use in the region, adoption of justified decisions, regarding the formation and implementation of spatial, urban planning, investment, and ecological areas is created.
\end{abstract}

Keywords: territorial development, integral assessment, region lands, quasimetric methods, geoinformation systems, land plot, land administration.

\section{Introduction}

In modern conditions there are ambiguous trends in the development of regions. During 2004-2016 there is a slowdown in the growth of the gross regional product from $12.1 \%$ to $2.4 \%$, respectively (Baranovsky, 2009). During 2016-2017 there is an increase in the volume of capital investments in the regional aspect by $27 \%$, the growth rate of the industrial output index is slowing down by $2.4 \%$, the building products index is growing by $8.9 \%$. Along with this, the ecological situation is worsening in the regional aspect. During 2015-2016 years there is an increase in emissions of pollutants and carbon dioxide into the air from stationary sources of pollution by $7.7 \%$ (Baranovs$\mathrm{ky}, 2009)$. The efficiency of land use in the regions is reduced due to low density and development of territories, a decrease in spatial support for territorial development, and an increase in problematic aspects regarding the implementation of urban planning policy. In such conditions, the urgent issue is the development and implementation of territorial development areas of land use in the region.

The results of the study of the land use territorial development in the region and its assessment are presented in Hordiyenko (2009), Lykhogrud (2016), Mamonov, Meteshkin and Grek (2017), Mamonov and Shterndok, (2017a, 2017b), Martin (2011), Nudelman and Sanzharovsky (2002), Perovych and Vynarchyk (2013), Prikhodko (2010), Stupen et al. (2006); A. Tretiak, V. Tretiak, Kovalyshyn, and V. Tretiak (2016), Umanets (2007), and Sala-i-Martin (1996). An important task is the formation of information and analytical support for the land use territorial development based on the development of a methodological approach for its integrated assessment. Thus, the research topic is relevant, and its development is timely.

${ }^{*}$ Corresponding author. E-mail: kostia.mamonov2017@gmail.com 


\section{Materials and methods}

To evaluate the territorial development of land use in the region, a methodological approach to its integrated evaluation is proposed. The essence of this approach is to use a set of integral, analytical, expert methods and methods for analyzing hierarchies, neural networks, determining the average geometric value, quasimetric methods, which allows to evaluate the level of territorial development of land use in the region, considering spatial, urban planning, investment and ecological factors.

The implementation of the methodological approach to the integrated assessment of the territorial development of land use in the region is based on the principles:

- scientific validity (characterized by the definition of the level of territorial development, based on scientific and methodological developments and regulatory support);

- complexity (includes a set of indicators that combine spatial, urban planning, investment, and ecological factors and is determined by interrelated actions aimed at determining the level of territorial development of land use in the region);

- systematic (determined by a multi-level system of spatial, urban planning, investment and ecological indicators, which create an estimated basis for the territorial development of land use in the region);

- integrity (characterized by the creation of a unified system for assessing the level of territorial development of land use in the region, provides an integral indicator for justified decision-making);

- goal orientation (determined by the orientation on the achievement of goals aimed at ensuring the territorial development of regional land use, considering a set of spatial, urban planning, investment, and ecological factors);

- structuring (characterized by a clear structure of indicators, which are determined at various levels);

- development (determined by the development of measures to ensure the territorial development of land use in the region on the basis of its established levels);

- adequacy (characterized by the definition of appropriate levels of territorial development, reflecting the directions and characteristics of the impact and changes occurring in the spatial, urban planning, investment, and ecological support).

The development and implementation of a methodological approach to an integrated assessment of the territorial development of land use in the region include a set of interrelated steps:

1. Formation of a complex of spatial, urban planning, investment and ecological factors affecting the territorial development of land use in the region based on existing scientific and methodological developments and regulatory support;

2. Construction of a multi-level system of factors;

3. The selection of the factors, which have the great- est impact on the territorial development of land use in the region through the use of a neural network method;

4. Formation of a multi-level system of indicators by applying quasimetric methods of transition from the proposed factors to the corresponding spatial, urban planning, investment, and ecological indicators, considering the values of the coefficients of assessment;

5. Assessment of the system of spatial, urban planning, investment and ecological indicators of the third level based on the use of analytical and expert assessment method;

6. Determination of spatial, urban planning, investment and ecological indicators of the second level by building mathematical models based on the method of estimating the geometrical mean;

7. Building a mathematical model for determining the integrated spatial, urban planning, investment, ecological indicators of territorial development of land use in the region;

8. Determination of weighting coefficients, which characterize the importance of spatial, urban planning, investment and ecological indicators in the system of territorial development of land use in the region based on the application of the hierarchy analysis method;

9. Determination of integrated spatial, urban planning, investment, ecological indicators of territorial development of land use in the region;

10. Assessment of the integral indicator of land use in the region;

11. Development and justification of a levels scale of land use territorial development in the region;

12. Interpretation of the results.

\section{Results}

A diagram of the development of a methodological approach to an integrated assessment of the land use territorial development in the region is presented in Figure 1. According to the proposed stages, it was determined that the formation of a complex of spatial, urban planning, investment and ecological factors influencing the territorial development of land use in the region is carried out on the basis of the analysis and systematization of existing scientific and methodological developments and regulatory support. Within the framework of the proposed stage, restrictions are imposed on the application of factors associated with land use and which influence the territorial development of the region. In addition, only the regional level is taken into account, where the influence of land use of cities, other settlements, a separate land plot at the state level is reduced. However, the presented levels are indirectly considered in the system of territorial development of land use in the region. Of particular importance are international experience and tools for the formation of spatial, urban planning, investment, and ecological 
factors. In this context, geo-information systems are of particular importance, and which are the complex tool for the formation and processing of information, allowing to build a multi-level system, which considers the influence of relevant factors.

The proposed GIS system allows building a modern integrated system of land administration. The construction of a multi-level factor system considers the spatial, urban planning, investment, and ecological areas and features, and consists of three levels. For visualization of a multilevel system of factors affecting the territorial development of land use in the region, a pyramid of levels was built. The selection of factors, which have the greatest influence on the territorial development of land use in the region is based on the application of the neural network method. This allows to justify the selection of factors through the use of mathematical tools, creates a quantitative basis for an integrated assessment of the territorial development of land use in the region. Formation of a multi-level system of indicators using quasimetric methods of transition from the proposed factors to the corresponding spatial, urban planning, investment, and ecological indicators. Thus, the corresponding coefficients, which justify the expediency of the transition are determined. Quasimetric transition models are constructed using mathematical tools.

The system assessment of the third level indicators is implemented using appropriate tools. An analytical method is used, which allows obtaining quantitative estimates of indicators based on data from the State Statistics Service of Ukraine and the State Service of Ukraine on geodesy, cartography, and cadastre. Within the analytical method, indicators are applied at the regional level. The method of expert assessments determines the spatial, urban planning, investment, and ecological indicators,

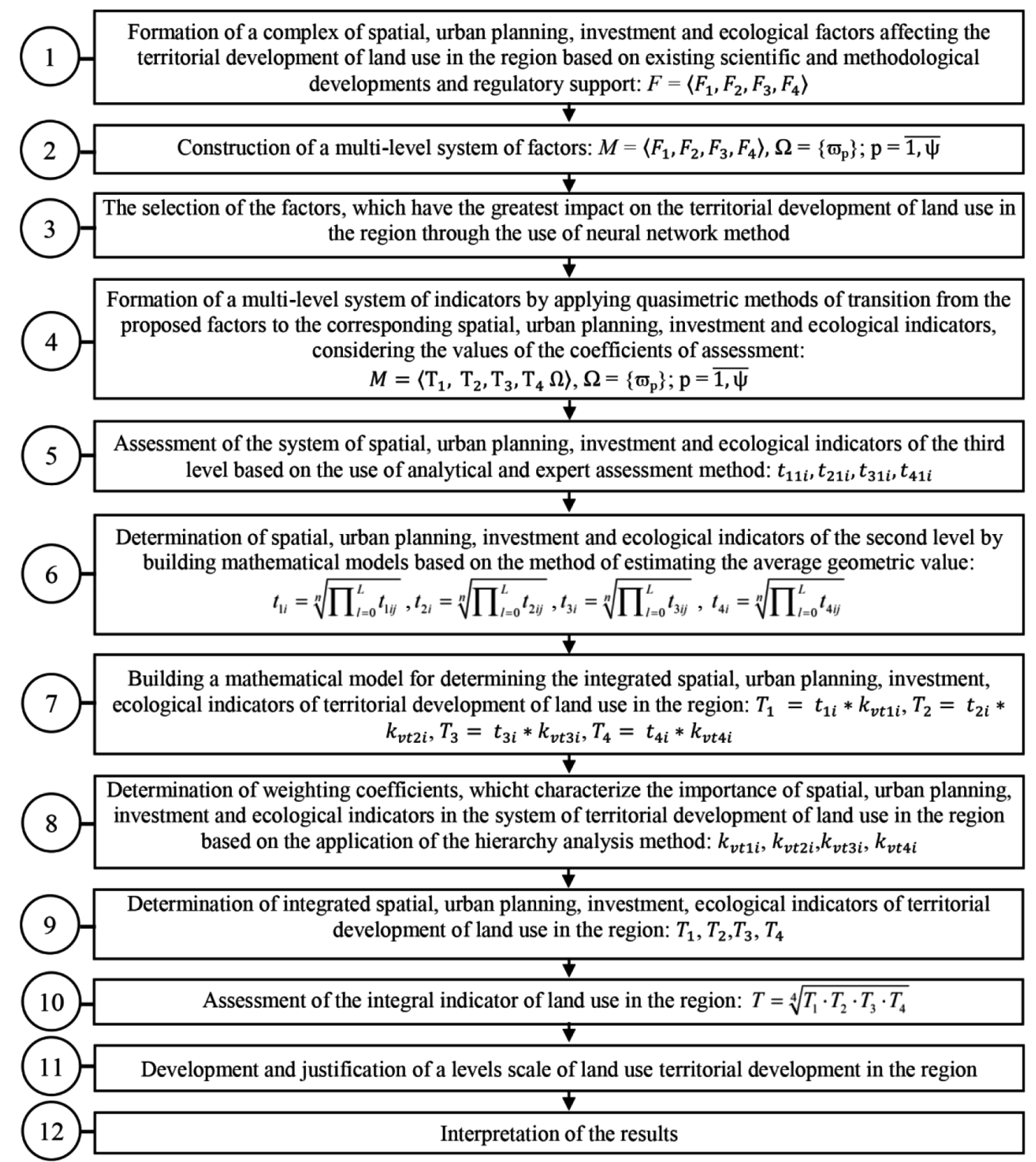

Figure 1. A diagram of the development of a methodological approach to an integrated assessment of the land use territorial development in the region 
which have qualitative characteristics. The quantitative scales for assessing the presented indicators are justified. Under applying the method of expert assessments, experts were selected.

The determination of second level indicators is based on the constructed mathematical models. The presented models are developed using the method of estimating the geometrical mean. At this stage, a restriction has been introduced, which consists in determining the mean values of the indicators, which reduce the influence of limiting factors and "smooth out" the trajectory of their changes.

A mathematical model for determining the integral indicators of the territorial development of land use, considering the value of the second-level indicators and weighting factors has been developed. Weighting factors, which determine the importance of the presented indicators in the system of territorial development of land use in the region are estimated on the basis of the hierarchy analysis method with the implementation of pairwise comparison of spatial, urban planning, investment, and ecological indicators.

The assessment of the integral indicator of land use in the region is carried out on the basis of the developed mathematical model. The value of the integral indicator

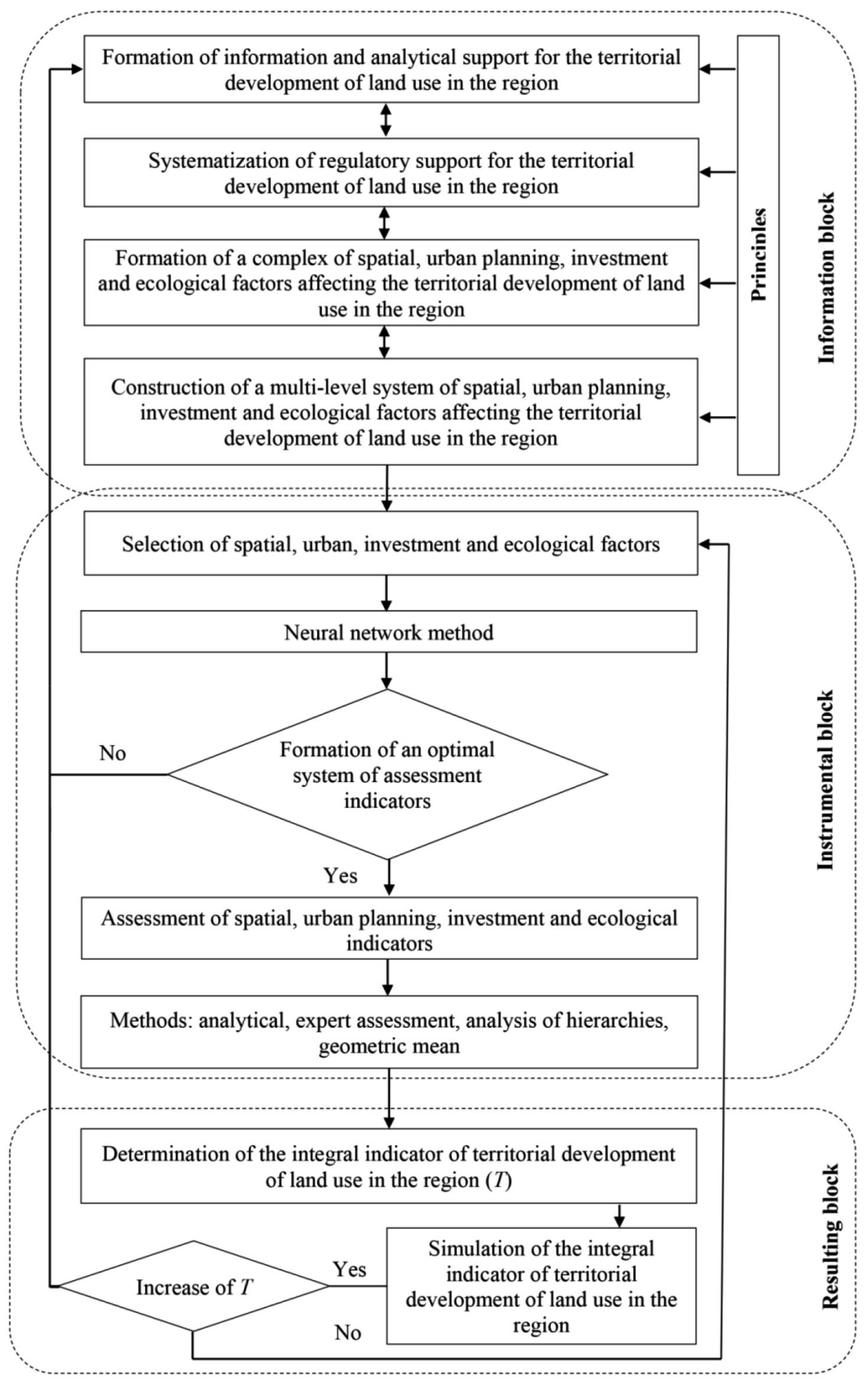

Figure 2. The algorithm for the development and implementation of a methodological approach to the integrated assessment of the territorial development of land use in the region 
forms the quantitative basis of the levels of territorial development of land use in the region.

The development and justification of the levels scale of land use territorial development in the region is formed in accordance with the scale of T. Saati, the value of the integral indicator in which varies from 0 to 10 and above. The resulting stage is the interpretation of the results, which allows developing measures to ensure the territorial development of land use in the region. The algorithm for the development and implementation of a methodological approach to the integrated assessment of the territorial development of land use in the region is presented in Figure 2. According to the presented algorithm, the development and implementation of the methodological approach include 3 blocks:

- information, which is characterized by the formation of information-analytical and regulatory support for the territorial development of land use in the region. Based on the certain support a set of spatial, urban planning, investment, and ecological factors, which affect the territorial development of land use in the region is formed. As a result of the information support application, the multi-level system of the abovementioned factors is built. In this block, an information base for the implementation of a methodological approach to the integral assessment of the territorial development of regional land use is formed. In addition, the estimated parameters are justified, which are used to determine the indicators;

- instrumental, which is determined by a set of methods and tools, which allow making the selection of spatial, urban planning, investment, and ecological factors by applying the neural networks method. As a result of the study, an optimal system of indicators for assessing the territorial development of land use in the region is being formed. In this block, the restriction on the optimality of certain indicators is introduced. In particular, at the third level, the level of optimality is determined in the range from 5 to 10 indicators, which are most important for ensuring the territorial development of land use in the region. It should be noted, if the condition of indicators optimization is not met ("No"), then it is necessary to return to the initial level of the information block "Formation of information and analytical support for the territorial development of land use in the region If the condition of indicators optimization is fulfilled ("Yes"), then the spatial, urban planning, investment and ecological indicators are assessed in accordance with the directions of the formation of a methodological approach to the integrated assessment of the regional land use territorial development. Wherein, analytical, expert assessments, analysis of hierarchies, the average geometric value methods are used;

- resulting, which is aimed at determining the integral indicator of territorial development of land use in the region in accordance with the developed methodological approach. For the development of justified measures to the growth of the integral indicator of territorial development, it is modeled and cause-effect relationships are established between the indicators that influence it. If the connections obtained by developing mathematical models are created ("Yes"), then the cycle of ensuring the territorial development of land use in the region is completed and research begins from the beginning. Along with this, a result regarding the growth of the integral indicator has been achieved and territorial development at the regional level in the area of land use has been ensured. If "No", the corresponding condition for ensuring territorial development is not fulfilled, and research is carried out on the selection of spatial, urban planning, investment, and ecological factors.

The proposed algorithm forms a closed system, which allows to develop and implement a methodological approach by applying of information support, appropriate methods, and models to achieve a result on the increase of the integral indicator of land use in the region, considering the spatial, urban planning, investment, and ecological characteristics.

\section{Conclusions}

As a result of the study, a methodological approach to integrated assessment has been developed, on the basis of which, the estimated basis for the territorial development of land use in the region, adoption of justified decisions, regarding the formation and implementation of spatial, urban planning, investment, and ecological areas is created.

\section{References}

Baranovsky, M. O. (2009). Naukovi zasady suspilno-heohrafichnoho vyvchennya silskykh depresyvnykh terytoriyy Ukrainy. Nizhyn: PE Lysenko M. M. (in Ukrainian).

Hordiyenko, V. P. (2009). Vyznachennya efektyvnosti vykorystannya zemel silskohospodarskoho pryznachennya za bahatokryterialnym pidkhodom. Agrosvit, 21, 27-31 (in Ukrainian). Retrieved from http://www.agrosvit.info/pdf/21_2009/7.pdf

Lykhogrud, O. (2016). Scientific approaches for determination values of land resources urban development systems in market conditions. Agrosvit, 6, 62-67. Retrieved from http://www. agrosvit.info/pdf/6_2016/13.pdf

Mamonov, K. A., Meteshkin, K. O., \& Grek, M. O. (2017). Definitions urban development factors that affect the use of city lands. Collected scientific works of Ukrainian State University of Railway Transport, 169, 174-182.

https://doi.org/10.18664/1994-7852.169.2017.111141

Mamonov, K. A., \& Shterndok, E. S. (2017a). Classification of spatial factors that affect the cost of land metropolis. Municipal Economy of Cities, 134, 138-142. Retrieved from http:// khg.kname.edu.ua/index.php/khg/article/view/5010/4964

Mamonov, K. A., \& Shterndok, E. S. (2017b). Metody i modeli otsinky formuvannya, rozpodilu ta vykorystannya zemel mehapolisu, shcho zastosovuyutsya u systemi heoinformatsiynoho zabezpechennya In Economic cybernetics: aspects of the formation and development of the electronic economy: 
materials of all-Ukrainian studies. Scientific pract. conference (pp. 92-96). Dnipro, Porohy, Ukraine (in Ukrainian).

Martin, A. H. (2011). Rehulyuvannya rynku zemel v Ukraini. Kyiv: AgrarMediaGroup (in Ukrainian).

Nudelman, V., \& Sanzharovsky, I. (2002). Rozrobka stratehii rozvytku terytorialnoi hromady: zahalni zasady metodyky. Kyiv: Date Bank Ukraine (in Ukrainian).

Perovych, I. L., \& Vynarchyk, L. V. (2013). Ekonomiko-matematychnyy pidkhid do otsinky zemli naselenykh punktiv na osnovi yikh funktsionalno-planuvalnoyi struktury. Geodesy, Cartography and Aerial Photography, 78, 241-247 (in Ukrainian).

Prikhodko, V. P. (2010). The methodological approaches to forming spatial organization of productive forces of the region. Efektyvna ekonomika, 12. Retrieved from http://www. economy.nayka.com.ua/?op $=1 \& z=1113$
Sala-i-Martin, X. X. (1996). Regional cohesion: evidence and theories of regional growth and convergence. European Economic Review, 40, 1325-1352. https://doi.org/10.1016/0014-2921(95)00029-1

Stupen, M. H., Hulko, R. Y., Mykula, O. Y., et. al. (2006). Teoretychni osnovy derzhavnoho zemelnoho kadastru (2nd ed.). Lviv: Novyy Svit-2000. (in Ukrainian).

Tretiak, A., Tretiak, V., Kovalyshyn, O., \& Tretiak, V. (2016). Improvement of the technique of rural lands assessment in Ukraine. Land Relations. Economist, 5, 38-40.

Umanets, T. V. (2007). Rehionalnyy ekonomichnyy rozvytok Ukrayiny: teoretychni osnovy upravlinnya, intehralna otsinka, diahnostyka. Donetsk: BIK (in Ukrainian). 